\title{
Multiple endocrine neoplasia type 2 (Sipple's syndrome): clinical and cytogenetic analysis of a kindred
}

\author{
ADRIANA ZATTERALE, M STABILE, V NUNZIATA*, G Di GIOVANNI*, \\ R VECCHIONE $\dagger$, AND V VENTRUTO \\ From the Medical Genetics Center, Cardarelli Hospital; and the Departments of Internal Medicine* \\ and Histopathology $\dagger$, Second Medical School, University of Naples, Naples, Italy.
}

SUMMARY This report describes the clinical and cytogenetic analysis of a kindred with multiple endocrine neoplasia type 2 (MEN-2 or Sipple's syndrome) in two generations. Medullary thyroid carcinoma was present in five members either as a large or as an occult tumour. Phaeochromocytoma was demonstrated in one severely hypertensive relative and urine vanillylmandelic acid (VMA) was increased in one normotensive member. Serum parathormone (PTH) was normal in all but one normocalcaemic patient of this family who did not have a history of nephrolithiasis. Prometaphase banding failed to detect a $20 \mathrm{p} 12 \cdot 2$ deletion or chromosome instability as observed in some MEN-2 families.

The group of hereditary diseases characterised by multiple endocrine neoplasia (MEN) is composed of three types known as MEN-1, MEN-2 (or 2a), and MEN-3 (or 2b). ${ }^{\mathbf{1}}$ The main distinguishing features of MEN-2 are the presence of medullary thyroid carcinoma or phaeochromocytoma or both in some cases.

MEN-2 locus mapping has been attempted through linkage studies with HLA and the P blood group. Jackson et $\mathrm{al}^{2}$ suggested a possible linear order of genes for MEN-2, P red cell antigen, and HLA on chromosome 6. Linkage between the loci for MEN-2 and HLA was recently excluded. ${ }^{3}$

Received for publication 6 May 1983.

Accepted for publication 15 August 1983.
Al-Saadi and Lieberman ${ }^{4}$ reported a high incidence of aneuploidy in leucocyte preparations from three patients with MEN-2. The finding was not confirmed by other cytogenetic investigations. ${ }^{56}$ Van Dyke et $a l^{6}$ reported a minor deletion of chromosome 20 in some MEN-2 families and Hsu et $\mathrm{al}^{7}$ showed chromosomal instability in patients with MEN-2.

We report slinical and cytogenetic studies in patients in a family with MEN-2.

\section{Case reports}

We studied six cases of MEN-2 in two generations. The pedigree of this family (fig 1) is consistent with

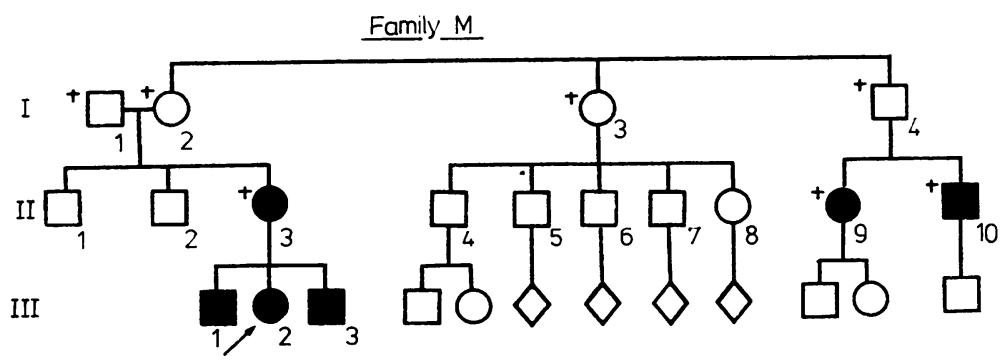

FIG 1 Pedigree of the family. 
TABLE Clinical and biochemical data.

\begin{tabular}{|c|c|c|c|c|c|c|c|c|c|c|c|c|}
\hline \multirow[t]{2}{*}{$\begin{array}{l}\text { Case } \\
\text { No }\end{array}$} & \multirow[t]{2}{*}{$\begin{array}{l}\text { Age }(y r) \\
\text { and sex }\end{array}$} & \multirow[t]{2}{*}{$\begin{array}{l}\text { Clinical } \\
\text { diagnosis }\end{array}$} & \multirow[t]{2}{*}{$\begin{array}{l}\text { Main } \\
\text { symptom }\end{array}$} & \multirow[t]{2}{*}{$\begin{array}{l}\text { Enlarged } \\
\text { thyroid } \\
\text { gland }\end{array}$} & \multirow[t]{2}{*}{ Hypertension } & \multicolumn{3}{|c|}{$\begin{array}{l}\text { Serum } C T(\mathrm{ng} / \mathrm{ml}) \\
\text { on pentagastrin } \\
(0 \cdot 5 \mu \mathrm{g} / \mathrm{kg} \mathrm{bw})\end{array}$} & \multirow[t]{2}{*}{$\begin{array}{l}C E A \\
(n g / m l)\end{array}$} & \multirow[t]{2}{*}{$\begin{array}{l}\text { Serum } \\
\text { PTH } \\
(\mathrm{ng} / \mathrm{ml})\end{array}$} & \multirow[t]{2}{*}{$\begin{array}{l}\text { Urinary } \\
\text { VMA } \\
(m g / 24 h)\end{array}$} & \multirow[t]{2}{*}{$\begin{array}{c}\text { Surgical } \\
\text { diagnosis }\end{array}$} \\
\hline & & & & & & $O^{\prime}$ & $2^{\prime}$ & $5^{\prime}$ & & & & \\
\hline 1 & $50 / \mathrm{F}$ & MTC & None & + & -. & 0.6 & $3 \cdot 5$ & 1.0 & 110 & 0.5 & 4 & MTC \\
\hline 2 & $18 / \mathrm{F}$ & MTC & Flush & + & - & 0.3 & $2 \cdot 0$ & $1 \cdot 5$ & 61 & 0.5 & $2 \cdot 5$ & MTC \\
\hline 3 & $16 / \mathrm{M}$ & MTC & None & - & - & 0.4 & $1 \cdot 0$ & 0.9 & 51 & $0 \cdot 8$ & $3 \cdot 2$ & Not operated \\
\hline 4 & $24 / M$ & MTC & None & - & - & 0.5 & $2 \cdot 5$ & $1 \cdot 2$ & 60 & 1.9 & $10 \cdot 5$ & Not operated \\
\hline 5 & $41 / F$ & MTC & $\begin{array}{l}\text { Abdominal } \\
\text { pain }\end{array}$ & - & - & $3 \cdot 5$ & & & 500 & & $6 \cdot 3$ & MTC \\
\hline 6 & $46 / \mathrm{M}$ & PH & Headache & - & + & & & & & & $34 \cdot 5$ & PH \\
\hline
\end{tabular}

MTC = medullary thyroid carcinoma, $\mathrm{PH}=$ phaeochromocytoma, $\mathrm{CT}=$-calcitonin, $\mathrm{CEA}=$ carcinoembryonic antigen, $\mathrm{PTH}=$ parathormone VMA $=$ vanillylmandelic acid.

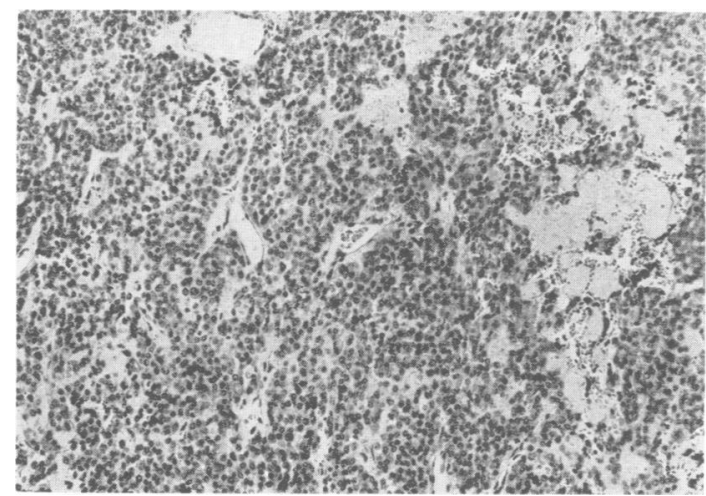

FIG 2 Solid tumour with amyloid deposits (case 1).

(Haematoxylin and eosin. Original magnification $\times 106)$.

autosomal dominant inheritance with high penetrance and variable expressivity with regard to age of onset and involvement of endocrine glands.

CASE 1 (II.3)

A 50 year old female, married with three children, was seen in December 1979 because a large, symptomless, slow growing, left sided thyroid nodule had been noted since she was 20 . Fine needle aspiration cytology displayed the typical amyloid dispersed cell pattern. High basal and pentagastrin stimulated serum calcitonin (CT) was found as well as high carcinoembryonic antigen (CEA) levels. Serum PTH and urine VMA were normal (table). Total thyroidectomy and midline lymph node dissection were performed. Histology showed a medullary thyroid carcinoma (fig 2) with lymph node involvement. The excised right inferior parathyroid was $10 \mathrm{~mm}$ in diameter with normal histology. After operation, CT and CEA were still raised and in the following 2 years metastases developed in the lymph nodes of the neck and the lumbar spine. The patient died in February 1982.
CASE 2 (III.2)

This was an 18 year old girl with a small multinodular goitre. Her only complaint was a recurrent and persistent cyanotic flush of the face and neck associated with even the most minor emotional reactions. Borderline basal CT serum levels, but high values after pentagastrin, were found. CEA levels were increased and PTH and urine VMA were normal (table). Total thyroidectomy was performed in February 1981 and histology showed a medullary carcinoma with normal lymph nodes. The excised left parathyroid was normal. Serum basal and stimulated CT, as well as CEA levels, were normal 2 months after the operation. She is now well and on thyroxine replacement.

CASE 3 (III.3)

This was a 16 year old boy with no symptoms. Thyroid examination revealed a nodule $\frac{1}{2} \mathrm{~cm}$ in diameter on the upper pole of the left thyroid lobe. Borderline basal serum CT but high pentagastrin response were found, as well as a definite increase in CEA levels. The serum PTH and urine VMA were normal. He refused total thyroidectomy.

CASE 4 (III.1)

This was a 24 year old man with no symptoms. Thyroid examination revealed a nodule $1 \mathrm{~cm}$ in diameter in the upper pole of the left thyroid lobe. Borderline serum CT but high pentagastrin response were found together with increased CEA serum levels. Serum PTH was nearly twice the upper limit of normal with normal blood calcium. Urine VMA was also increased but with no hypertension. $\mathrm{He}$ refused operation.

\section{CASE 5 (II.9)}

This was a 41 year old female, married with one daughter (who was not investigated). She was operated on in 1973 for medullary thyroid carcinoma and received local radiotherapy because of positive lymph node involvement. Admitted in 1977 because 
of abdominal pain, she was found to have disseminated metastases (liver, lymphatics, and lumbar spine). Very high $\mathrm{CT}$ and CEA serum levels were found and normal urine VMA excretion (table). She received a complete course of Adriblastine with partial remission. She died in August 1978.

CASE 6 (II.10)

This was a 45 year old male, married with one son. When he was 40 he started to suffer from undiagnosed hypertension. He was admitted to hospital in 1977 with very severe hypertension and loss of consciousness and died 2 days later. Necropsy showed a right adrenal, $5 \mathrm{~cm}$ in diameter, with phaeochromocytoma and a large area of infarction.

\section{Hormonal methods}

Serum CT was assayed by radioimmunoassay (RIA) $^{8}$ (Byk Gulden reagents). In normal controls CT basal value was less than $0.2 \mathrm{ng} / \mathrm{ml}$ and pentagastrin stimulated peak (Peptavlon, ICI, $0.5 \mu \mathrm{g} / \mathrm{kg}$ bw) was found to be less than $0.6 \mathrm{ng} / \mathrm{ml}$.

Serum PTH was assayed by RIA ${ }^{9}$ (Byk Gulden reagents), with an antiserum recognising the carboxy terminal fragment as well as the entire hormone. Upper normal PTH limit was $1 \cdot 1 \mathrm{ng} / \mathrm{ml}$.

Serum CEA assayed by RIA ${ }^{10}$ (CIS-SORIN reagents) was less than $10 \mathrm{ng} / \mathrm{ml}$ in normal non-smokers.

Urine VMA, determined according to Pisano et al,$^{11}$ was found to be less than $6.5 \mathrm{mg} / 24$ hours in normal controls.

\section{Cytogenetics}

Three members of this family (III.1, III.2, and III.3) were available for cytogenetic studies. Chromosome preparations from peripheral blood lymphocytes were analysed (about 50 mitoses for each subject). $\mathbf{R}$ banding of prometaphase chromosomes, obtained after 15 minutes' incubation with colcemid, ${ }^{12}$ failed to detect a 20 p deletion or any other chromosome aberrations.

\section{Linkage studies}

We attempted linkage studies for red cell antigens ABO, Rh, MNSs, P, K, Fy, Le, Lu, and Jk in III.1, III.2, III.3, and their father. The results were not informative.

\section{Discussion}

The association between thyroid carcinoma and phaeochromocytoma was emphasised by Sipple. ${ }^{13}$
This familial association was defined as part of a $\stackrel{\mathbb{Q}}{+}$ syndrome of multiple endocrine neoplasia type $2 \vec{F}$ (MEN-2), ${ }^{14}$ including medullary thyroid and adrenal $\stackrel{\rho}{+}$ tumours, described by Sipple, and primary hyper- $\frac{\text { C }}{2}$ parathyroidism. Later these patients were identified $\frac{\bar{\sigma}}{\bar{D}}$ as having MEN-2 $\mathbf{a}^{1}$ if suffering from medullary $\frac{\sigma}{\sigma}$ thyroid carcinoma $(100 \%$ of cases $)$ phaeo- $\varnothing$ chromocytoma $(50 \%)$, and hyperparathyroidism $\%$ $(50 \%)$, or as having MEN-2 $b^{1}$ or MEN-3 ${ }^{15}$ if $\vec{\circ}$ suffering from medullary thyroid carcinoma $(100 \%)$, phaeochromocytoma $(50 \%)$, hyperparathyroidism $\vec{\omega}$ (rare), marfanoid habitus $(100 \%)$, intestinal ganglioneuromatosis $(100 \%)$, and mucosal neuromas $(100 \%)$.

In the family studied by us, medullary thyroid $\stackrel{\sim}{\sim}$ carcinoma was present in all but one member. There was a manifest phaeochromocytoma in case 6 and in $\varnothing$ case 4 there was probable adrenal medullary 은 hyperplasia because of the high urine VMA excretion. No history of hyperparathyroidism or nephro- $\rightarrow$ lithiasis was recorded in this family. A moderate increase of serum PTH was documented on several $\overrightarrow{0}$ occasions in case 4 . In cases 1 and 2 the excised parathyroids showed no evidence of hyperplasia. Parathyroid hyperplasia in this syndrome is mostly diagnosed on the basis of high PTH levels with normal serum calcium. ${ }^{5}$ Microscopical observation may give rise to differing opinions which can be solved by electron microscopy. Mucosal neuromas or $\stackrel{\mathbb{Q}}{\Omega}$ intestinal ganglioneuromatosis were not present in $\overrightarrow{\vec{B}}$ this family. A slight appearance of marfanoid habitus was noted in some members.

Concerning the cytogenetic aspects of the syndrome, Hsu et al ${ }^{7}$ studied some patients with MEN-2 and observed chromosomal instability with a preponderance of aberrations such as dicentrics, acentric fragments, and marker chromosomes. Van Dyke et $a l^{6}$ studied six families of with MEN-2, in which 10 patients in five families $₹$ showed a minor deletion of the short arm of chro- $\frac{\text { O }}{3}$ mosome $20(20 \mathrm{p} 12 \cdot 2)$. In the sixth family the only patient showed a normal karyotype.

These findings are not surprising. Wilms's tumour and retinoblastoma are known examples of $\sigma$ hereditary neoplastic diseases sometimes associated $N$ with chromosomal aberrations, $11 p$ deletion ${ }^{16}$ and $\underset{\omega}{N}$ 13q interstitial deletion ${ }^{17}$ respectively. Furthermore, chromosomal instability has been found in various 0 Mendelian diseases with neoplastic diathesis, such as Fanconi's anaemia, Bloom's disease, Louis-Barr $\stackrel{\mathcal{D}}{+}$ syndrome, etc.

The finding of a typical deletion or chromosomal instability in MEN-2 could be of value in preclinical and antenatal diagnosis of the syndrome. Today, a growing body of evidence suggests that the locus for MEN-2 is probably on the short arm of chromosome 
20. Our negative results as regards the $20 \mathrm{p}$ deletion and chromosomal instability do not contradict previous cytogenetic evidence, as the deletion could be so small that even high resolution banding might have failed to detect it.

Another hypothesis is that the gene could be present but abnormal and functionally equivalent to a deleted one. In Wilms's tumour and retinoblastoma the typical deletion is not always present.

\section{References}

1 Chong GC, Beahrs OH, Sizemore GW, Woolner LN. Medullary carcinoma of the thyroid gland. Cancer $1975 ; 35: 695-704$.

2 Jackson CE, Conneally PM, Sizemore GW, Tashjian AH Jr. Possible linear order of genes for endocrine neoplasia type 2 , the $P$ red cell antigen and HL-A on chromosome 6. Birth Defects 1976;XII:159-64.

${ }^{3}$ Simpson NE, Falk J. Exclusion of linkage between the loci for multiple endocrine neoplasia type 2 (MEN-2) and HLA. Hum Genet 1982;60:157.

4 Al-Saadi A, Lieberman L. Familial medullary thyroid carcinoma. Recent Prog Horm Res 1972;28:446.

5 Melvin KEW, Toshjion AH, Miller HH. Studies in familial (medullary) thyroid carcinoma. Recent Prog Horm Res 1972;28:399-470.

6 Van Dyke DL, Jackson CE, Babu VR. Localization of autosomal dominant multiple endocrine neoplasia 2 syndrome (MEN 2) to 20p12.2. Cytogenet Cell Genet 1982; 32:324.

7 Hsu TC, Pathak S, Samaan N, Hickey RC. Chromosome instability in patients with medullary carcinoma of the thyroid. JAMA $1981 ; 246: 2046-8$.
8 Heath H, Sizemore GW. Plasma calcitonin in normal man: differences between men and women. $J$ Clin Invest 1977;60:1135-40.

9 Arnaud CD, Tsao HS, Littledike T. Radioimmunoassay of human parathyroid hormone in serum. J Clin Invest $1971 ; 50: 21$.

10 Egan ML, Lautenschleger JT, Colligan JE, Todd CW. Radioimmune assay of carcinoembryonic antigen. Immunochemistry 1972;9:289-99.

11 Pisano JJ, Crout JR, Abraham D. Determination of 3-methoxy-4-hydroxy-mandelic acid in urine. Clin Chim Acta 1962;7:285-91.

12 Franke U, Oliver N. Quantitative analysis of highresolution trypsin-Giemsa bands on human prometaphase chromosomes. Hum Genet 1978;45:137-65.

13 Sipple JH. The association of pheochromocytoma with carcinoma of the thyroid gland. Am J Med 1961;31:163-6.

14 Steiner AL, Goodman HD, Powers JR. Study of a kindred with pheochromocytoma, medullary thyroid carcinoma, hyperparathyroidism and Cushing's disease: multiple endocrine neoplasia, type 2. Medicine 1968;47: 371-409.

15 Kaini MRA, Dexter RN, Burzynski NJ, Johnston CC Jr. Mucosal neuroma, pheochromocytoma and medullary thyroid carcinoma: multiple endocrine neoplasia, type 3 . Medicine 1975;54:89-112.

16 Franke U, Holmes LB, Atkins L, Riccardi VM. AniridiaWilms' tumor association: evidence for specific deletion of 11p13. Cytogenet Cell Genet 1979;24:185-92.

17 Wilson MG, Ebbin AJ, Towner JW, Spencer WH. Chromosomal anomalies in patients with retinoblastoma. Clin Genet 1977;12:1-8.

Correspondence and requests for reprints to Dr Adriana Zatterale, Via S d'Acquisto 13, 80136 Napoli, Italy. 